\title{
Human immunoglobulin $G$ levels of viruses and associated glioma risk
}

\author{
Sara Sjöström • Ulf Hjalmars · Per Juto · Göran Wadell • \\ Göran Hallmans · Anne Tjönneland · Jytte Halkjaer • \\ Jonas Manjer • Martin Almquist • Beatrice S. Melin
}

Received: 14 January 2011 / Accepted: 10 June 2011 / Published online: 30 June 2011

(C) The Author(s) 2011. This article is published with open access at Springerlink.com

\begin{abstract}
Few consistent etiological factors have been identified for primary brain tumors. Inverse associations to asthma and low levels of varicella-zoster virus, immunoglobulin (Ig) levels in prevalent cases have indicted a role for the immune system in the development of glioma. Because samples from prevalent cases of glioma could be influenced by treatments such as steroids and chemotherapy, we investigated pre-diagnostic samples from three large Scandinavian cohorts. To test the hypothesis that immune response levels to these viruses are associated etiologically with glioma risk, we investigated pre-
\end{abstract}

S. Sjöström $(\bowtie) \cdot$ B. S. Melin

Department of Radiation Sciences, Oncology, Umeå University, 90187 Umeå, Sweden

e-mail: sara.sjostrom@onkologi.umu.se

U. Hjalmars

Department of Clinical Sciences, Paediatrics, Umeå University, 90187 Umeå, Sweden

P. Juto $\cdot$ G. Wadell

Department of Clinical Microbiology, Umeå University,

90187 Umeå, Sweden

G. Hallmans

Department of Public Health and Clinical Medicine,

Nutritional Research, Umeå University, 90187 Umeå, Sweden

A. Tjönneland · J. Halkjaer

Institute of Cancer Epidemiology, Danish Cancer Society,

2100 Copenhagen, Denmark

J. Manjer

Department of Surgery, Malmö University Hospital,

Malmö University, Malmö, Sweden

M. Almquist

Department of Surgery, Lund University Hospital,

Lund University, Lund, Sweden diagnostic immunoglobulin levels for cytomegalovirus (CMV), varicella-zoster virus (VZV), adenovirus (Ad), and Epstein-Barr virus (EBV) including the nuclear antigen (EBNA1) using plasma samples from 197 cases of adult glioma and 394 controls collected from population-based cohorts in Sweden and Denmark. Low VZV IgG levels were marginally significantly more common in glioma cases than the controls (odds ratio $(\mathrm{OR})=0.68,95 \% \mathrm{CI}$ $0.41-1.13)$ for the fourth compared with the first quartile ( $p=0.06$ for trend). These results were more prominent when analyzing cases with blood sampling at least 2 years before diagnosis $(\mathrm{OR}=0.63, \quad 95 \%$ CI $0.37-1.08)$ $(p=0.03)$. No association with glioma risk was observed for CMV, EBV, and adenovirus.

Keywords Glioma - Glioblastoma - Immunoglobulin G · Virus · Case-control study

\section{Introduction}

Gliomas are the most common primary malignant brain tumor. Although glioma treatment strategies-surgery, irradiation, and chemotherapy-have improved, the prognosis is still poor compared with many other human malignancies [1, 2]. Recently, the concomitant use of chemotherapy and irradiation and the use of the antiangiogenic treatment bevacizumab have improved prognosis [3]. As few etiological factors for glioma have been identified, few effective preventive strategies have been developed $[4,5]$. The only confirmed risk factors are high dose of ionizing radiation and some rare hereditary predisposing conditions that are only found in less than $5 \%$ of all glioma cases [6, 7]. A familial aggregation of gliomas has been observed in several studies [8-10] and recently 
five genes with low penetrance have been strongly associated with glioma risk [11, 12].

The question if viruses might cause, promote, or prevent human brain tumors is of great interest as viruses have been proven to cause several other types of cancers [13]. Earlier studies have shown evidence of viral DNA or proteins in tumor tissue for example JCV and SV40 [14, 15]. CMV and adenoviruses have also been reported to be present in brain tumor tissue [16-20]. It is, however, unclear whether their presence is due to the immunosuppressive environment in the tumor, making it a predilection site for viruses, or whether the presence of viruses in the tumor is due to an etiological impact.

Immunologic response to viral infections may be associated with the risk of developing glioma or glioblastoma [1]. Statistically significant inverse associations of adult glioma to both history of chickenpox and immunoglobulin $\mathrm{G}$ antibodies against varicella-zoster virus have been reported [21-23]. Patients with glioma and glioblastoma had levels of anti-varicella-zoster virus immunoglobulin $\mathrm{G}$ significantly lower than controls, indicating that the level of immune response to viruses may play a role in glioma induction or progression. Although some studies speculated whether the lowered IgG-levels preceded tumor diagnosis, this has not been clarified. Furthermore, several studies have shown an inverse association between occurrence of allergic diseases and brain tumors, a finding that indicates that the immune system function is important for glioma etiology [24-26]. In this study, we investigated the association between $\operatorname{IgG}$ levels of four viruses in prediagnostic samples and whether these levels were associated with glioma risk.

\section{Materials and methods}

Study population

This case-control study was based on 197 glioma cases and 394 controls from three cohorts: Northern Sweden Health and Disease Study—The Medical Biobank (NSHDS) (79 glioma cases and 158 controls); the Malmö Diet and Cancer Study (MDCS) (45 glioma cases and 90 controls); and the Diet, Cancer, and Health cohort from Copenhagen ( 73 glioma cases and 146 controls). The controls were matched for age, sex, and cohort. The male/female distribution was $47.7 \% / 52.3 \%$, and the median ages at blood sampling were 55.4 years in cases and 55.3 in controls. Table 1 describes the cases and controls from the different cohorts. The diagnosis of glioma was identified through linkage to the local cancer registries. The registries have close to $100 \%$ coverage of cancer diagnoses since both clinicians and pathologists in Sweden and Denmark are legally obligated to report cancer diagnoses.

For the Swedish cases, we were able to receive classification of the tumors according to SNOMED (Systematized Nomenclature of Medicine). A total of 61 glioblastoma (SNOMED 94403), 8 astrocytoma grade 1-2 (SNOMED 94003, 94203, 94213), 32 astrocytoma grade 3 (SNOMED 94013), 14 oligodendroglioma (SNOMED 94503, 94513, 94603), 2 oligoastrocytoma (SNOMED 93823), and 5 malignant glioma (SNOMED 93803), were seen in the Swedish cases. SNOMED classification was not available on the cases from Copenhagen.

\section{Northern Sweden health and disease study}

NSHDS is a population-based cohort consisting of blood samples and questionnaires from three subcohorts [27]: The Västerbotten Intervention Program (VIP); the Västerbotten Mammary Screening Program; and the Northern Sweden MONICA (Monitoring Trends and Determinants in Cardiovascular Disease) Project. By June 2006, the VIP cohort comprised 94,630 samples from 74,690 individuals. These individuals were asked to participate in a health study the year they turned 40, 50, and 60. Since 1995, blood samples were collected for the Mammary Screening Program and have been added to the VIP cohort. From 1997, repeated screening was started in the Mammography Screening Program in the age group 50-69. The MONICA project provided 11,000 random blood samples from 7,500 individuals ranging from 25 to 64 years old. All cohorts were population based and contained 166,000 randomly

Table 1 Descriptive table showing the male/female ratio (numbers and percentages for cases shown, and percentages for controls are the same as for cases) and median age at blood sample for the whole cohort and each cohort

\begin{tabular}{|c|c|c|c|c|c|c|c|c|}
\hline & \multicolumn{2}{|l|}{ All } & \multicolumn{2}{|l|}{ NSHDS } & \multicolumn{2}{|l|}{ Malmö } & \multicolumn{2}{|l|}{ Copenhagen } \\
\hline & Case & Control & Case & Control & Case & Control & Case & Control \\
\hline All & 197 & 394 & 79 & 158 & 45 & 90 & 73 & 146 \\
\hline Male & $94(47.7 \%)$ & 188 & $33(41.8 \%)$ & 66 & $25(55.6 \%)$ & 50 & $36(49.3 \%)$ & 72 \\
\hline Female & $103(53.3 \%)$ & 206 & $46(58.2 \%)$ & 92 & $20(44.4 \%)$ & 40 & $37(50.7 \%)$ & 74 \\
\hline Median age at blood sample & 55.4 & 55.3 & 50.1 & 50.1 & 58.1 & 58.0 & 57.5 & 57.6 \\
\hline
\end{tabular}


selected men and women and 278,000 sample occasions. Seventy-nine individuals were later diagnosed with a glioma [28].

\section{The Malmö Diet and Cancer Study}

The Malmö Diet and Cancer Study (MDCS) is a population-based prospective cohort study. Between 1991 and 1996, men and women between the ages of 44 and 77 were recruited with the main goal to study the impact of diet on cancer incidence and mortality. In all, 28,098 blood samples were stored in a medical biological bank. Regular follow-up with the national registries of mortality and cancer was done, and 45 individuals from the cohort were later diagnosed with a glioma $[29,30]$.

Diet, cancer, and health—Denmark

The Diet, Cancer, and Health study is a population-based prospective cohort study from Denmark where 80,996 men and 79,729 women were invited to participate between December 1993 and May 1997. The study included individuals between 50 and 64 years of age, born in Denmark, and with no diagnosis of cancer registered in the Danish Cancer Registry. Blood samples were obtained from 57,053 participants. From these individuals, 73 were later diagnosed with glioma [31].

The controls were collected from living individuals with no history of primary brain tumor at the time of case diagnosis and matched for age, gender, and calendar year of sampling. All individuals had a written informed consent and the study was approved by the local ethical committee at Umeå University.

\section{Laboratory methods}

IgG antibodies for adenovirus, CMV, and VZV were analyzed, by in-house enzyme-linked immunosorbent assays (ELISA), at the Department of Virology at Umeå University. The origins of viral antigens used were for adenovirus a mixture of two local strains of Ad 3 and Ad 5, for CMV laboratory strain CMV 169 and for VZV a local strain. The analyses were blinded and performed in duplicate in a pair of wells coated with viral antigen and control antigen. In each run, high and low positive controls and negative controls were included. The sera were analyzed in a final dilution of $1 / 441$, in which dilution there is a high correlation to antibody levels expressed as titers. The antibody activity in the single dilution of the sample was expressed in arbitrary units (AU), i.e., as a percentage of the netabsorbance (absorbance of virus-coated well) of the high positive control. Samples with $<10$ AU were negative. The IgG-anti-EBNA-1 response to EBV was measured using a commercial ELISA from Biotest Germany according to the manufacture's instructions. The antibody activity of the sample was expressed in AU as a percentage of the positive control and the manufacturer's cut-off value for presence of antibodies was used.

The IgG response to EBV viral capsid antigen (VCA) was analyzed by immunoflourescence assay in a high screening dilution (1/320) using butyric acid-stimulated P3HR1 lymphoma cells. The samples were blinded to case-control status and an experienced microscopist read all the samples (PJ). The fluorescence activity grading was aggregated to three categories: "low" (negative in 1/320 dilution), "intermediate" (weak positive), and "high" (intermediate and strong positive). Negative samples in $1 / 320$ dilution were identified by re-analysis in $1 / 20$ dilution. VCA was not used in the statistical analyses except for ruling out active infection. All methods are accredited at The Swedish Board for Accreditation and Conformity Assessment.

\section{Statistical methods}

The proportions of cases and controls that were positive for the different immunoglobulin $\mathrm{G}$ and the mean age at blood sample in these groups were calculated and were estimated separately for glioma and for glioblastoma (SNOMED 94403). In the glioblastoma group, only the Swedish cases were available for analysis as the SNOMED code was not available for the Danish cases. The IgG antibody levels were divided into four same-sized quartiles, and cut-offs were based on $\operatorname{IgG}$ levels in controls. Binary logistic regression was used to compare the quartiles between cases and controls, and the lowest quartile was set as a reference. All odds ratios (OR) were adjusted for sex, cohort (Umeå, Malmö, and Denmark), and age at blood sampling. Separate analyses were also performed on cases with blood samples taken at least 2 years before diagnosis to omit any bias associated with the preclinical phase of the disease. The correlation between genotypes and IgG quartiles was performed by chi-square test using Fisher's exact test and $p<0.05$ was identified as the level for significance. SPSS software (v. 17) was used for the analyses.

\section{Results}

Overall, there were high levels of seropositivity for the studied viruses, varying from 85.2 to $100 \%$, and this result was similar in cases and controls (Table 2). The analyses were successful for close to $100 \%$ of the subsets of immunoglobulin. The mean age at blood samples did not differ significantly between the cases and the controls 
Table 2 Incidence of subjects positive for immunoglobulin $G$ antibodies, in adenovirus, cytomegalovirus, Epstein-Barr virus, and varicellazoster virus in the Umeå, Malmö, and Copenhagen cohorts

\begin{tabular}{|c|c|c|c|c|c|c|c|c|c|c|}
\hline & \multicolumn{2}{|l|}{ All subjects } & \multicolumn{2}{|l|}{ Controls } & \multicolumn{3}{|l|}{ Glioma cases } & \multicolumn{3}{|c|}{ Glioblastoma Sweden } \\
\hline & $\begin{array}{l}\text { No. positive/ } \\
\text { total no. }\end{array}$ & $\begin{array}{l}\text { Positive } \\
(\%)\end{array}$ & $\begin{array}{l}\text { No. positive/ } \\
\text { total no. }\end{array}$ & $\begin{array}{l}\text { Positive } \\
\text { (\%) }\end{array}$ & $\begin{array}{l}\text { No. positive/ } \\
\text { total no. }\end{array}$ & $\begin{array}{l}\% \\
\text { positive }\end{array}$ & $\begin{array}{l}p \text { - } \\
\text { value }\end{array}$ & $\begin{array}{l}\text { No. positive/ } \\
\text { total no. }\end{array}$ & $\begin{array}{l}\% \\
\text { positive }\end{array}$ & $\begin{array}{l}p- \\
\text { value }^{\mathrm{a}}\end{array}$ \\
\hline \multicolumn{11}{|c|}{ Immunoglobulin $\mathrm{G}$ antibodies } \\
\hline Adenovirus & $584 / 589$ & 99.2 & $388 / 393$ & 98.7 & 196/196 & 100 & 0.18 & $61 / 61$ & 100 & 1.00 \\
\hline Cytomegalovirus & $504 / 589$ & 85.6 & $335 / 393$ & 85.2 & $169 / 196$ & 86.2 & 0.80 & $53 / 61$ & 86.9 & 1.00 \\
\hline $\begin{array}{l}\text { Epstein-Barr } \\
\text { virus }\end{array}$ & $511 / 587$ & 87.1 & $347 / 391$ & 88.7 & $164 / 196$ & 83.7 & 0.09 & $54 / 61$ & 88.5 & 0.15 \\
\hline $\begin{array}{l}\text { Varicella-zoster } \\
\quad \text { virus }\end{array}$ & $582 / 589$ & 98.8 & $389 / 393$ & 99.0 & 193/196 & 98.5 & 0.69 & $59 / 61$ & 96.7 & 0.26 \\
\hline
\end{tabular}

Cases/controls and Swedish cases (Umeå and Malmö) with glioblastoma shown separately. Information on tumor subtypes was not available for the cases from Copenhagen. No significant difference in numbers positive between cases and controls

${ }^{a}$ Controls from Copenhagen excluded in the analysis

Table 3 Mean ages at blood sample for cases and controls from the Umeå, Malmö, and Copenhagen cohorts

\begin{tabular}{|c|c|c|c|c|}
\hline & \multicolumn{2}{|l|}{ Positive } & \multicolumn{2}{|c|}{ Negative } \\
\hline & $\begin{array}{l}\text { Mean } \\
\text { age } \\
\text { (years) }\end{array}$ & $\begin{array}{l}\text { No. of } \\
\text { Subjects }\end{array}$ & $\begin{array}{l}\text { Mean } \\
\text { age } \\
\text { (years) }\end{array}$ & $\begin{array}{l}\text { No. of } \\
\text { Subjects }\end{array}$ \\
\hline \multicolumn{5}{|c|}{ Immunoglobulin $\mathrm{G}$ antibodies } \\
\hline \multicolumn{5}{|l|}{ Controls } \\
\hline Adenovirus & 54.7 & 389 & 58.7 & 5 \\
\hline Cytomegalovirus & 54.8 & 336 & 54.6 & 58 \\
\hline Epstein-Barr virus ${ }^{a}$ & 54.6 & 347 & 56.7 & 44 \\
\hline $\begin{array}{l}\text { Varicella-zoster } \\
\quad \text { virus }\end{array}$ & 54.7 & 390 & 59.2 & 4 \\
\hline \multicolumn{5}{|l|}{ Cases } \\
\hline Adenovirus & 54.8 & 197 & & 0 \\
\hline Cytomegalovirus & 54.7 & 170 & 55.4 & 27 \\
\hline Epstein-Barr virus $^{\mathrm{a}}$ & 55.0 & 164 & 53.8 & 32 \\
\hline $\begin{array}{l}\text { Varicella-zoster } \\
\quad \text { virus }\end{array}$ & 54.7 & 194 & 60.3 & 3 \\
\hline
\end{tabular}

Positive or negative for immunoglobulin $\mathrm{G}$ antibody levels for adenovirus, cytomegalovirus, Epstein-Barr virus, and varicella-zoster virus. There are no differences in mean age for cases and controls as the controls are matched to cases on age and year of blood sample

${ }^{a}$ Based on immunoglobulin $\mathrm{G}$ antibody levels analyzed using EBNA

(Table 3). The quartiles did not differ significantly between glioma and glioblastoma cases and controls, but a nonsignificant trend of lower VZV odds ratios was seen in the second, third, and fourth quartile $(\mathrm{OR}=0.85,95 \% \mathrm{CI}$ $0.53-1.36 ;$ OR $=0.74,95 \%$ CI $0.45-1.23$; and $\mathrm{OR}=$ $0.68,95 \%$ CI $0.41-0.13$, respectively $\quad(p=0.06)$ (Table 4). The trend test was significant when restricting the analyses to glioma cases with a latency of more than 2 years from sampling to glioma diagnosis (total 164 cases) (p-trend test, $p=0.03$ ) (Table 5).

\section{Discussion}

To our knowledge, the present study is the first comprehensive study where virus-serology for EBV, CMV, VZV, and adenovirus is analyzed in samples from glioma/glioblastoma cases taken before diagnosis. This has previously been studied in astrocytoma for JC virus, BK virus, and simian virus 40, but no association to risk was found [32].

We found that immunoglobulin $G$ to varicella-zoster virus was lower in cases versus controls especially in samples taken at least 2 years before diagnosis, a finding that indicates there might be an etiological association. No association between antibody levels for CMV, EBV, or adenoviruses and glioma risk was found.

Varicella-zoster virus (VZV) is neurotropic, and viruses remain permanent in neural ganglia after a primary infection. Furthermore, several studies have shown that immunoglobulin $\mathrm{G}$ levels of VZV are lower in serum from glioma cases, especially glioblastoma cases, compared with controls [21-23]. This lower level of VZV in serum from glioma cases could be because the tumor itself or the early treatment of the tumor influenced the immune response levels. Our data show a significant trend for lower VZV IgG levels especially in cases with blood samples taken more than 2 years before diagnosis, indicating that this could be a true etiological association. A medical history of asthma and allergies have been inversely correlated to glioma in several case-control studies indicating that the immune system may be a key player in glioma development [33, 34]. The biological reasons for this association are currently unknown. A previously stated theory is that a strong immune system more easily could detect viruses and therefore be able to inhibit the growth of small cancer cell clusters [22]. That can be demonstrated by the recent study showing that $\mathrm{T}$-cell infiltration impacts on glioblastoma survival [35]. 
Table 4 Cases and controls odds ratios (OR) and 95\% confidence intervals (CI) for risk of glioma in the Umeå, Malmö, and Copenhagen cohorts and glioblastoma in the Umeå and Malmö cohorts

\begin{tabular}{|c|c|c|c|c|c|c|c|c|}
\hline & \multicolumn{2}{|c|}{ Cases } & \multicolumn{2}{|c|}{$\begin{array}{l}\text { Glioma cases versus } \\
\text { controls }\end{array}$} & \multicolumn{2}{|c|}{$\begin{array}{l}\text { Glioblastoma } \\
\text { cases }\end{array}$} & \multicolumn{2}{|c|}{$\begin{array}{l}\text { Glioblastoma cases versus } \\
\text { controls }^{\mathrm{b}}\end{array}$} \\
\hline & No. & $\%$ & OR & $(95 \% \mathrm{CI})$ & No. & $\%$ & OR & $(95 \% \mathrm{CI})$ \\
\hline \multicolumn{9}{|l|}{ Adenovirus, negative versus positive } \\
\hline \multicolumn{9}{|l|}{ Adenovirus, quartiles } \\
\hline $1 \mathrm{st}$ & 40 & 20.4 & 1.0 & & 16 & 26.2 & 1.0 & \\
\hline 2nd & 59 & 30.1 & 1.39 & $(0.85-2.28)$ & 16 & 26.2 & 0.81 & $(0.37-1.79)$ \\
\hline $3 \mathrm{rd}$ & 42 & 21.4 & 1.07 & $(0.63-1.81)$ & 15 & 24.6 & 0.95 & $(0.42-2.12)$ \\
\hline 4th & 55 & 28.1 & 1.27 & $(0.76-2.12)$ & 14 & 23.0 & 0.57 & $(0.25-1.31)$ \\
\hline p-trend & & & 0.49 & & & & 0.28 & \\
\hline Cytomegalovirus, negative versus positive & & & 1.08 & $(0.66-1.78)$ & & & 0.97 & $(0.43-2.28)$ \\
\hline \multicolumn{9}{|l|}{ Cytomegalovirus, quartiles } \\
\hline $1 \mathrm{st}$ & 48 & 24.5 & 1.0 & & 15 & 24.6 & 1.0 & \\
\hline 2nd & 62 & 31.6 & 1.18 & $(0.73-1.90)$ & 19 & 31.1 & 0.93 & $(0.42-2.05)$ \\
\hline $3 r d$ & 41 & 20.9 & 1.08 & $(0.85-1.38)$ & 14 & 23.0 & 0.96 & $(0.65-1.43)$ \\
\hline 4th & 45 & 23.0 & 1.06 & $(0.90-1.24)$ & 13 & 21.3 & 0.98 & $(0.75-1.27)$ \\
\hline p-trend & & & 0.67 & & & & 0.36 & \\
\hline Epstein-Barr virus ${ }^{\mathrm{a}}$, negative versus positive & & & 0.64 & $(0.39-1.06)$ & & & 0.47 & $(0.18-1.23)$ \\
\hline \multicolumn{9}{|l|}{ Epstein-Barr virus ${ }^{\mathrm{a}}$, quartiles } \\
\hline $1 \mathrm{st}$ & 58 & 29.6 & 1.0 & & 17 & 27.9 & 1.0 & \\
\hline 2nd & 46 & 23.5 & 0.79 & $(0.49-1.29)$ & 15 & 24.6 & 0.76 & $(0.34-1.70)$ \\
\hline $3 \mathrm{rd}$ & 43 & 21.9 & 0.71 & $(0.44-1.16)$ & 16 & 26.2 & 0.71 & $(0.33-1.55)$ \\
\hline 4th & 49 & 25.0 & 0.78 & $(0.49-1.26)$ & 13 & 21.3 & 0.63 & $(0.28-1.44)$ \\
\hline p-trend & & & 0.25 & & & & 0.17 & \\
\hline Varicella-zoster virus, negative versus positive & & & 0.66 & $(0.15-3.01)$ & & & 0.34 & $(0.05-2.14)$ \\
\hline \multicolumn{9}{|l|}{ Varicella-zoster virus, quartiles } \\
\hline 1 st & 55 & 28.1 & 1.0 & & 12 & 19.7 & 1.0 & \\
\hline 2nd & 55 & 28.1 & 0.85 & $(0.53-1.36)$ & 26 & 42.6 & 1.71 & $(0.78-3.74)$ \\
\hline $3 \mathrm{rd}$ & 43 & 21.9 & 0.74 & $(0.45-1.23)$ & 16 & 26.2 & 1.08 & $(0.45-2.57)$ \\
\hline 4th & 43 & 21.9 & 0.68 & $(0.41-1.13)$ & 7 & 11.5 & 0.39 & $(0.14-1.08)$ \\
\hline p-trend & & & 0.06 & & & & 0.02 & \\
\hline
\end{tabular}

All odds ratios are adjusted for cohort, sex, and age at blood sample

${ }^{a}$ Based on immunoglobulin $\mathrm{G}$ antibody levels analyzed using EBNA

${ }^{\mathrm{b}}$ Glioblastoma cases from the Umeå and Malmö cohorts. Copenhagen cases and controls excluded

Of course, a confounder may explain this association in our study as well as in previous studies.

Many reports have been published concerning potentially oncogenic viruses, notably some herpes viruses such as human cytomegalovirus (HCMV), varicella-zoster virus (VZV), Epstein-Barr virus (EBV), and adenoviruses. Human cytomegalovirus (HCMV) is a ubiquitous herpes virus that is of particular interest and has long been suspected to play a role in the development of human cancers [36]. This virus has an affinity for glial cells and may possibly play an important role in glioma etiology. This affinity has been shown to influence glioma cells in several ways that might contribute to tumor progression, resulting in altered tumor cell properties such as reduced apoptosis, increased cell invasion, telomerase activation, and enhanced angiogenesis [37, 38]. A study published in 2002 reported that human cytomegalovirus (HCMV) gene products and nucleic acids were present in all 27 glioma samples investigated but not in other brain tissue [39]. Recently, this finding has been confirmed by other research groups [17, 18]. Although a causal relationship between HCMV and human cancer has not been clearly proven, it is obvious that the virus may have a potential to promote oncogenesis or tumor progression in human cells.

Epstein-Barr-virus infections (EBV) have shown a clear association with human malignancies and some CNS tumors [40]. An increased risk for primary central nervous system lymphoma occurs in immunodeficient patients [41]. 
Table 5 Cases and controls odds ratios (OR) and 95\% confidence intervals (CI) for risk of glioma in the Umeå, Malmö, and Copenhagen cohorts and glioblastoma in the Umeå and Malmö cohorts

\begin{tabular}{|c|c|c|c|c|c|c|c|c|}
\hline & \multicolumn{2}{|c|}{ Cases } & \multicolumn{2}{|c|}{$\begin{array}{l}\text { Glioma cases versus } \\
\text { controls }\end{array}$} & \multicolumn{2}{|c|}{$\begin{array}{l}\text { Glioblastoma } \\
\text { cases }\end{array}$} & \multicolumn{2}{|c|}{$\begin{array}{l}\text { Glioblastoma cases versus } \\
\text { controls }^{\mathrm{b}}\end{array}$} \\
\hline & No. & $\%$ & OR & $(95 \% \mathrm{CI})$ & No. & $\%$ & OR & $(95 \%$ CI $)$ \\
\hline \multicolumn{9}{|l|}{ Adenovirus, negative versus positive } \\
\hline \multicolumn{9}{|l|}{ Adenovirus, quartiles } \\
\hline 1 st & 35 & 21.3 & 1.0 & & 14 & 24.1 & 1.0 & \\
\hline 2nd & 44 & 26.8 & 1.15 & $(0.67-1.96)$ & 16 & 27.6 & 0.94 & $(0.42-2.11)$ \\
\hline $3 \mathrm{rd}$ & 38 & 23.2 & 1.12 & $(0.64-1.93)$ & 14 & 24.1 & 1.01 & $(0.43-2.37)$ \\
\hline 4th & 47 & 28.7 & 1.28 & $(0.75-2.19)$ & 14 & 24.1 & 0.67 & $(0.28-1.58)$ \\
\hline p-trend & & & 0.40 & & & & 0.71 & \\
\hline Cytomegalovirus, negative versus positive & & & 1.29 & $(0.74-2.25)$ & & & 0.93 & $(0.40-2.16)$ \\
\hline \multicolumn{9}{|l|}{ Cytomegalovirus, quartiles } \\
\hline $1 \mathrm{st}$ & 39 & 23.8 & 1.0 & & 15 & 25.9 & 1.0 & \\
\hline 2 nd & 49 & 29.9 & 1.14 & $(0.68-1.91)$ & 17 & 29.3 & 0.86 & $(0.38-1.92)$ \\
\hline $3 \mathrm{rd}$ & 36 & 22.0 & 1.07 & $(0.83-1.38)$ & 14 & 24.1 & 0.93 & $(0.62-1.39)$ \\
\hline 4 th & 40 & 24.4 & 1.05 & $(0.88-1.24)$ & 12 & 20.7 & 0.95 & $(0.73-1.24)$ \\
\hline p-trend & & & 0.92 & & & & 0.66 & \\
\hline Epstein-Barr virus ${ }^{\mathrm{a}}$, negative versus positive & & & 0.72 & $(0.42-1.23)$ & & & 0.44 & $(0.17-1.14)$ \\
\hline \multicolumn{9}{|l|}{ Epstein-Barr virus ${ }^{\mathrm{a}}$, quartiles } \\
\hline $1 \mathrm{st}$ & 46 & 28.0 & 1.0 & & 17 & 29.3 & 1.0 & \\
\hline 2nd & 42 & 25.6 & 0.90 & $(0.54-1.50)$ & 15 & 25.9 & 0.76 & $(0.34-1.70)$ \\
\hline $3 \mathrm{rd}$ & 36 & 22.0 & 0.78 & $(0.46-1.31)$ & 14 & 24.1 & 0.63 & $(0.28-1.40)$ \\
\hline 4th & 40 & 24.4 & 0.79 & $(0.47-1.32)$ & 12 & 20.7 & 0.57 & $(0.24-1.32)$ \\
\hline p-trend & & & 0.27 & & & & 0.35 & \\
\hline Varicella-zoster virus, negative versus positive & & & 0.54 & $(0.12-2.47)$ & & & 0.32 & $(0.05-2.03)$ \\
\hline \multicolumn{9}{|l|}{ Varicella-zoster virus, quartiles } \\
\hline $1 \mathrm{st}$ & 48 & 29.3 & 1.0 & & 12 & 20.7 & 1.0 & \\
\hline 2nd & 47 & 28.7 & 0.84 & $(0.51-1-37)$ & 24 & 41.4 & 1.59 & $(0.72-3.50)$ \\
\hline $3 \mathrm{rd}$ & 35 & 21.3 & 0.70 & $(0.41-1.19)$ & 15 & 25.9 & 1.03 & $(0.43-2.47)$ \\
\hline 4th & 34 & 20.7 & 0.63 & $(0.37-1.08)$ & 7 & 12.1 & 0.39 & $(0.14-1.08)$ \\
\hline p-trend & & & 0.029 & & & & 0.031 & \\
\hline
\end{tabular}

Only cases with at least 2 years between blood sample and glioma/glioblastoma diagnosis included. All odds ratios are adjusted for cohort, sex, and age at blood sample

${ }^{\text {a }}$ Based on immunoglobulin $\mathrm{G}$ antibody levels analyzed using EBNA

${ }^{\mathrm{b}}$ Glioblastoma cases from the Umeå and Malmö cohorts. Copenhagen cases and controls excluded

EBV might be involved in pathogenesis of other brain tumors, i.e., glioma. There is, however, no conclusive evidence of any glial tumor associated with EBV infections $[42,43]$. Adenovirus has been shown to be neurotropic and one study has shown it to be present in childhood brain tumors [20]. We did not find any evidence of an association of EBV or adenovirus immunoglobulin levels with glioma risk.

As the blood samples were taken before diagnosis, antibody levels were not affected by any anti-tumor therapy, an important difference compared with previous studies. These viral infections are common in the general population and the seroprevalences in cases and controls were high, limiting the statistical power of this study. Larger nested case-control studies within cohorts-using both pre-diagnostic and post-diagnostic serological samples in combination with matched tumor sample to discern potential effects on antibody levels by tumor tissue or treatment effects-could provide valuable information. In conclusion, the present study indicates that immune response to the varicella-zoster virus might be associated with glioma risk.

Acknowledgments We would like to acknowledge Irene Eriksson for careful analyses of the samples. We would also like to acknowledge our funders for this study, The Umeå University Hospital grant, 
Young research award at Umeå University, The Acta Oncologica foundation supported B Melin through the Royal Swedish Academy of Science, The Northern Sweden Cancer Foundation and the Swedish Cancer Society and the Swedish Research Council. We would also like to acknowledge all participating individuals in the study.

Open Access This article is distributed under the terms of the Creative Commons Attribution Noncommercial License which permits any noncommercial use, distribution, and reproduction in any medium, provided the original author(s) and source are credited.

\section{References}

1. Wrensch M, Minn Y, Chew T, Bondy M, Berger MS (2002) Epidemiology of primary brain tumors: current concepts and review of the literature. Neuro Oncol 4(4):278-299

2. Ohgaki H (2009) Epidemiology of brain tumors. Methods Mol Biol 472:323-342

3. Friedman HS, Prados MD, Wen PY, Mikkelsen T, Schiff D, Abrey LE et al (2009) Bevacizumab alone and in combination with irinotecan in recurrent glioblastoma. J Clin Oncol 27(28): 4733-4740

4. Martin-Villalba A, Okuducu AF, von Deimling A (2008) The evolution of our understanding on glioma. Brain Pathol 18(3):455-463

5. Inskip PD, Linet MS, Heineman EF (1995) Etiology of brain tumors in adults. Epidemiol Rev 17(2):382-414

6. Reuss D, von Deimling A (2009) Hereditary tumor syndromes and gliomas. Recent Results Cancer Res 171:83-102

7. Bondy ML, Scheurer ME, Malmer B, Barnholtz-Sloan JS, Davis FG, Il'yasova D et al (2008) Brain tumor epidemiology: consensus from the brain tumor epidemiology consortium. Cancer 113(7 Suppl):1953-1968

8. Malmer B, Gronberg H, Bergenheim AT, Lenner P, Henriksson R (1999) Familial aggregation of astrocytoma in northern Sweden: an epidemiological cohort study. Int J Cancer 81(3):366-370

9. Wrensch M, Lee M, Miike R, Newman B, Barger G, Davis R et al (1997) Familial and personal medical history of cancer and nervous system conditions among adults with glioma and controls. Am J Epidemiol 145(7):581-593

10. Hemminki K, Tretli S, Sundquist J, Johannesen TB, Granstrom C (2009) Familial risks in nervous-system tumours: a histology-specific analysis from Sweden and Norway. Lancet Oncol 10(5): 481-488

11. Shete S, Hosking FJ, Robertson LB, Dobbins SE, Sanson M, Malmer B et al (2009) Genome-wide association study identifies five susceptibility loci for glioma. Nat Genet 41(8):899-904

12. Wrensch M, Jenkins RB, Chang JS, Yeh RF, Xiao Y, Decker PA et al (2009) Variants in the CDKN2B and RTEL1 regions are associated with high-grade glioma susceptibility. Nat Genet 41(8): 905-908

13. Levine AJ (2009) The common mechanisms of transformation by the small DNA tumor viruses: the inactivation of tumor suppressor gene products: p53. Virology 384(2):285-293

14. Del Valle L, Gordon J, Assimakopoulou M, Enam S, Geddes JF, Varakis JN et al (2001) Detection of JC virus DNA sequences and expression of the viral regulatory protein $\mathrm{T}$-antigen in tumors of the central nervous system. Cancer Res 61(10):4287-4293

15. Huang H, Reis R, Yonekawa Y, Lopes JM, Kleihues P, Ohgaki H (1999) Identification in human brain tumors of DNA sequences specific for SV40 large T antigen. Brain Pathol 9(1):33-42
16. Cobbs CS, Soroceanu L, Denham S, Zhang W, Kraus MH (2008) Modulation of oncogenic phenotype in human glioma cells by cytomegalovirus IE1-mediated mitogenicity. Cancer Res 68(3): 724-730

17. Mitchell DA, Xie W, Schmittling R, Learn C, Friedman A, McLendon RE et al (2008) Sensitive detection of human cytomegalovirus in tumors and peripheral blood of patients diagnosed with glioblastoma. Neuro Oncol 10(1):10-18

18. Scheurer ME, Bondy ML, Aldape KD, Albrecht T, El-Zein R (2008) Detection of human cytomegalovirus in different histological types of gliomas. Acta Neuropathol 116(1):79-86

19. Cobbs CS, Soroceanu L, Denham S, Zhang W, Britt WJ, Pieper R et al (2007) Human cytomegalovirus induces cellular tyrosine kinase signaling and promotes glioma cell invasiveness. J Neurooncol 85(3):271-280

20. Kosulin K, Haberler C, Hainfellner JA, Amann G, Lang S, Lion T (2007) Investigation of adenovirus occurrence in pediatric tumor entities. J Virol 81(14):7629-7635

21. Wrensch M, Weinberg A, Wiencke J, Masters H, Miike R, Barger $\mathrm{G}$ et al (1997) Does prior infection with varicella-zoster virus influence risk of adult glioma? Am J Epidemiol 145(7):594-597

22. Wrensch M, Weinberg A, Wiencke J, Miike R, Barger G, Kelsey K (2001) Prevalence of antibodies to four herpesviruses among adults with glioma and controls. Am J Epidemiol 154(2):161-165

23. Wrensch M, Weinberg A, Wiencke J, Miike R, Sison J, Wiemels $\mathrm{J}$ et al (2005) History of chickenpox and shingles and prevalence of antibodies to varicella-zoster virus and three other herpesviruses among adults with glioma and controls. Am J Epidemiol 161(10):929-938

24. Schwartzbaum J, Ahlbom A, Malmer B, Lonn S, Brookes AJ, Doss $\mathrm{H}$ et al (2005) Polymorphisms associated with asthma are inversely related to glioblastoma multiforme. Cancer Res 65(14): $6459-6465$

25. Wiemels JL, Wiencke JK, Patoka J, Moghadassi M, Chew T, McMillan A et al (2004) Reduced immunoglobulin E and allergy among adults with glioma compared with controls. Cancer Res 64(22):8468-8473

26. Linos E, Raine T, Alonso A, Michaud D (2007) Atopy and risk of brain tumors: a meta-analysis. J Natl Cancer Inst 99(20):1544-1550

27. Hallmans G, Agren A, Johansson G, Johansson A, Stegmayr B, Jansson JH et al (2003) Cardiovascular disease and diabetes in the Northern Sweden health and disease study cohort-evaluation of risk factors and their interactions. Scand J Public Health Suppl 61:18-24

28. Sundstrom P, Svenningsson A, Nystrom L, Forsgren L (2004) Clinical characteristics of multiple sclerosis in Vasterbotten County in northern Sweden. J Neurol Neurosurg Psychiatry 75(5):711-716

29. Manjer J, Carlsson S, Elmstahl S, Gullberg B, Janzon L, Lindstrom M et al (2001) The Malmo Diet and Cancer Study: representativity, cancer incidence and mortality in participants and non-participants. Eur J Cancer Prev 10(6):489-499

30. Manjer J, Elmstahl S, Janzon L, Berglund G (2002) Invitation to a population-based cohort study: differences between subjects recruited using various strategies. Scand J Public Health 30(2): $103-112$

31. Tjonneland A, Olsen A, Boll K, Stripp C, Christensen J, Engholm $\mathrm{G}$ et al (2007) Study design, exposure variables, and socioeconomic determinants of participation in diet, cancer and health: a population-based prospective cohort study of 57,053 men and women in Denmark. Scand J Public Health 35(4):432-441

32. Rollison DE, Helzlsouer KJ, Alberg AJ, Hoffman S, Hou J, Daniel R et al (2003) Serum antibodies to JC virus, BK virus, simian virus 40, and the risk of incident adult astrocytic brain tumors. Cancer Epidemiol Biomarkers Prev 12(5):460-463 
33. Schlehofer B, Blettner M, Preston-Martin S, Niehoff D, Wahrendorf J, Arslan A et al (1999) Role of medical history in brain tumour development. Results from the international adult brain tumour study. Int J Cancer 82(2):155-160

34. Wigertz A, Lonn S, Schwartzbaum J, Hall P, Auvinen A, Christensen HC et al (2007) Allergic conditions and brain tumor risk. Am J Epidemiol 166(8):941-950

35. Lohr J, Ratliff T, Huppertz A, Ge Y, Dictus C, Ahmadi R, et al (2011) Effector T-cell infiltration positively impacts survival of glioblastoma patients and is impaired by tumor-derived transforming growth factor-betas. Clin Cancer Res. doi:10.1158/ 1078-0432.CCR-10-2557

36. Michaelis M, Doerr HW, Cinatl J (2009) The story of human cytomegalovirus and cancer: increasing evidence and open questions. Neoplasia 11(1):1-9

37. Straat K, Liu C, Rahbar A, Zhu Q, Liu L, Wolmer-Solberg N et al (2009) Activation of telomerase by human cytomegalovirus. J Natl Cancer Inst 101(7):488-497
38. Soderberg-Naucler C (2008) HCMV microinfections in inflammatory diseases and cancer. J Clin 41(3):218-223

39. Cobbs CS, Harkins L, Samanta M, Gillespie GY, Bharara S, King $\mathrm{PH}$ et al (2002) Human cytomegalovirus infection and expression in human malignant glioma. Cancer Res 62(12):3347-3350

40. Klein E, Kis LL, Klein G (2007) Epstein-Barr virus infection in humans: from harmless to life endangering virus-lymphocyte interactions. Oncogene 26(9):1297-1305

41. Blumenthal DT, Raizer JJ, Rosenblum MK, Bilsky MH, Hariharan S, Abrey LE (1999) Primary intracranial neoplasms in patients with HIV. Neurology 52(8):1648-1651

42. Poltermann S, Schlehofer B, Steindorf K, Schnitzler P, Geletneky K, Schlehofer JR (2006) Lack of association of herpesviruses with brain tumors. J Neurovirol 12(2):90-99

43. Neves AM, Thompson G, Carvalheira J, Trindade JC, Rueff J, Caetano JM et al (2008) Detection and quantitative analysis of human herpesvirus in pilocytic astrocytoma. Brain Res 1221: $108-114$ 